University of Nebraska - Lincoln

DigitalCommons@University of Nebraska - Lincoln

\title{
Influence of Dietary Crude Protein Concentration and Source on Potential Ammonia Emissions from Beef Cattle Manure
}

\author{
N. A. Cole \\ USDA-ARS \\ R. N. Clark \\ USDA-ARS \\ R. W. Todd \\ USDA-ARS
}

C. R. Richardson

Texas Tech University, Lubbock

A. Gueye

Texas Tech University, Lubbock

See next page for additional authors

Follow this and additional works at: https://digitalcommons.unl.edu/usdaarsfacpub

Part of the Agricultural Science Commons

Cole, N. A.; Clark, R. N.; Todd, R. W.; Richardson, C. R.; Gueye, A.; Greene, L. W.; and McBride, K., "Influence of Dietary Crude Protein Concentration and Source on Potential Ammonia Emissions from Beef Cattle Manure" (2005). Publications from USDA-ARS / UNL Faculty. 266.

https://digitalcommons.unl.edu/usdaarsfacpub/266

This Article is brought to you for free and open access by the U.S. Department of Agriculture: Agricultural Research Service, Lincoln, Nebraska at DigitalCommons@University of Nebraska - Lincoln. It has been accepted for inclusion in Publications from USDA-ARS / UNL Faculty by an authorized administrator of DigitalCommons@University of Nebraska - Lincoln. 


\section{Authors}

N. A. Cole, R. N. Clark, R. W. Todd, C. R. Richardson, A. Gueye, L. W. Greene, and K. McBride 


\section{JOURNAL OF ANIMAL SCIENCE}

The Premier Journal and Leading Source of New Knowledge and Perspective in Animal Science

\section{Influence of dietary crude protein concentration and source on potential ammonia emissions from beef cattle manure}

N. A. Cole, R. N. Clark, R. W. Todd, C. R. Richardson, A. Gueye, L. W. Greene and K. McBride

J Anim Sci 2005. 83:722-731.

The online version of this article, along with updated information and services, is located on the World Wide Web at:

http://jas.fass.org/cgi/content/full/83/3/722 


\title{
Influence of dietary crude protein concentration and source on potential ammonia emissions from beef cattle manure ${ }^{1,2,3}$
}

\author{
N. A. Cole ${ }^{* 4}$, R. N. Clark*, R. W. Todd*, C. R. Richardson $\dagger$, A. Gueye $\dagger$, \\ L. W. Greene\$, and K. McBride \\ *ARS, USDA, Conservation and Production Research Laboratory, Bushland, TX 79012; \\ $\dagger$ Department of Animal Science and Food Technology, Texas Tech University, Lubbock 79409; and \\ $\ddagger$ Texas Agricultural Experiment Station, Amarillo 79106
}

\begin{abstract}
Emissions of ammonia, as well as other gases and particulates, to the atmosphere are a growing concern of livestock producers, the general public, and regulators. The concentration and ruminal degradability of $\mathrm{CP}$ in beef cattle diets may affect urinary and fecal excretion of $\mathrm{N}$ and thus may affect ammonia emissions from beef cattle feed yards. To determine the effects of dietary CP concentration and degradability on potential ammonia emissions, 54 steers were randomly assigned to nine dietary treatments in a $3 \times 3$ factorial arrangement of treatments. Treatments consisted of three dietary CP concentrations (11.5, 13 , and $14.5 \%)$ and three supplemental urea:cottonseed meal ratios (100:0, 50:50, and 0:100 of supplemental N). Steers were confined to tie stalls, and feces and urine excreted were collected and frozen after approximately 30, 75, and $120 \mathrm{~d}$ on feed. One percent of daily urine and feces
\end{abstract}

excretion were added to polyethylene chambers containing 1,550 g of soil. Chambers were sealed, and ammonia emissions were trapped in an acid solution for $7 \mathrm{~d}$ using a vacuum system. As the protein concentration in the diet increased from 11.5 to $13 \%$, in vitro daily ammonia emissions increased $(P<0.01) 60$ to $200 \%$, due primarily to increased urinary $\mathrm{N}$ excretion. As days on feed increased, in vitro ammonia emissions also increased $(P<0.01)$. Potential ammonia losses were highly correlated $(P<0.01)$ to urinary $\mathrm{N}\left(\mathrm{r}^{2}=0.69\right)$, urinary urea-N $\left(\mathrm{r}^{2}=0.58\right)$ excretion, serum urea-N concentration $\left(\mathrm{r}^{2}=0.52\right)$, and intake of degradable protein $\mathrm{N}\left(\mathrm{r}^{2}=0.23\right)$. Although dietary composition can affect daily ammonia losses, daily ammonia emissions must be balanced with effects on animal performance to determine optimal protein concentrations and forms in the diet.

Key Words: Air Quality, Ammonia, Beef Cattle, Diet, Emissions, Feedyards, Protein

\section{Introduction}

Emissions of ammonia $\left(\mathrm{NH}_{3}-\mathrm{N}\right)$, as well as other gases and particulates, to the atmosphere are a growing concern of livestock producers, the general public, and regulators. Concentrated animal feeding operations

\footnotetext{
${ }^{1}$ Contribution from the ARS, USDA, Conservation and Production Res. Lab., Bushland, TX 79012, in cooperation with the Texas Agric. Exp. Stn., Texas A\&M Univ., College Station 77843 and Texas Tech Univ., Lubbock 79409.

${ }^{2}$ The mention of trade or manufacturer names is made for information only and does not imply an endorsement, recommendation, or exclusion by ARS-USDA, the Texas Agric. Exp. Stn., or Texas Tech Univ.

${ }^{3}$ Appreciation is extended to J. Herring and A. Mason for assistance in conducting these studies.

${ }^{4}$ Correspondence: P.O. Drawer 10 (phone: 806-356-5748; fax: 806356-5750; e-mail: nacole@cprl.ars.usda.gov).

Received June 10, 2004.

Accepted November 29, 2004.
}

(CAFO) have been implicated as a major contributor to these emissions. Most $\mathrm{NH}_{3}-\mathrm{N}$ emitted from $\mathrm{CAFO}$ is produced from the microbial hydrolysis of urinary urea to ammonium $\left(\mathrm{NH}_{4}-\mathrm{N}\right)$ and carbon dioxide. Thus, factors that increase urinary $\mathrm{N}$ excretion could increase $\mathrm{NH}_{3}-\mathrm{N}$ emissions (Erickson et al., 2001a). However, factors such as urine $\mathrm{pH}$ and soil moisture (Luebes et al., 1974), or chemical composition of excreted urine (Whitehead et al., 1989) can also affect $\mathrm{NH}_{3}-\mathrm{N}$ emissions.

Typical feed yard finishing diets for beef cattle contain approximately 13 to $13.5 \% \mathrm{CP}$ and are routinely supplemented with 0.5 to $1.0 \%$ urea to provide adequate ruminally degradable intake protein (DIP; Galyean and Gleghorn, 2001). Altering the concentration and ruminal degradability of $\mathrm{N}$ in the diet can potentially affect the quantity and form of $\mathrm{N}$ excreted by cattle. In general, as $\mathrm{N}$ intake increases, excretion of urinary urea $\mathrm{N}$ increases (Gueye et al., 2003b; McBride et al., 2003), and as the dietary ratio of DIP:ruminally unde- 
Table 1. Composition of experimental diets, \% DM basis

\begin{tabular}{|c|c|c|c|c|c|c|c|c|c|}
\hline \multirow[b]{2}{*}{ Ingredient } & \multicolumn{3}{|c|}{$11.5 \% \mathrm{CP}$} & \multicolumn{3}{|c|}{$13.0 \% \mathrm{CP}$} & \multicolumn{3}{|c|}{$14.5 \% \mathrm{CP}$} \\
\hline & $100: 0^{\mathrm{a}}$ & $50: 50$ & $0: 100$ & $100: 0$ & $50: 50$ & $0: 100$ & $100: 0$ & $50: 50$ & $0: 100$ \\
\hline Corn & 79.68 & 77.84 & 75.90 & 79.12 & 75.22 & 71.25 & 78.58 & 72.70 & 66.75 \\
\hline Alfalfa & 10.0 & 10.0 & 10.0 & 10.0 & 10.0 & 10.0 & 10.0 & 10.0 & 10.0 \\
\hline Molasses & 4.0 & 4.0 & 4.0 & 4.0 & 4.0 & 4.0 & 4.0 & 4.0 & 4.0 \\
\hline Fat & 3.0 & 3.0 & 3.0 & 3.0 & 3.0 & 3.0 & 3.0 & 3.0 & 3.0 \\
\hline Urea & 0.52 & 0.26 & 0.0 & 1.08 & 0.53 & 0.0 & 1.62 & 0.80 & 0.0 \\
\hline CSM & 0 & 2.0 & 4.1 & 0 & 4.25 & 8.5 & 0 & 6.40 & 12.80 \\
\hline Limestone & 0.80 & 0.90 & 1.00 & 0.80 & 1.00 & 1.25 & 0.80 & 1.10 & 1.45 \\
\hline Supplement ${ }^{\mathrm{b}}$ & 2.0 & 2.0 & 2.0 & 2.0 & 2.0 & 2.0 & 2.0 & 2.0 & 2.0 \\
\hline \multicolumn{10}{|c|}{ Chemical component } \\
\hline $\mathrm{DIP}, \% \mathrm{DM}$ & 6.58 & 6.27 & 5.98 & 8.17 & 7.52 & 6.92 & 9.69 & 8.73 & 7.83 \\
\hline DIP, \% CP & 57.2 & 54.5 & 52.0 & 62.8 & 57.8 & 53.2 & 66.8 & 60.2 & 54.0 \\
\hline
\end{tabular}

${ }^{a}$ Urea:cottonseed meal ratio $(\mathrm{N}$ basis) of supplemental protein. $\mathrm{CSM}=$ cottonseed meal. $\mathrm{DIP}=$ ruminally degradable intake protein derived from NRC (2000) values.

${ }^{\mathrm{b}}$ Contained $61.1 \%$ ground sorghum, $0.002 \%$ cobalt chloride, $0.15 \%$ copper sulfate, $0.0045 \%$ potassium iodide, $0.5 \%$ iron sulfate, $2 \%$ magnesium oxide, $0.75 \%$ manganese sulfate, $20 \%$ potassium chloride, $12.5 \%$ salt, $0.001 \%$ sodium selenite, $1 \%$ zinc sulfate, $0.3 \%$ vitamin E premix (227,000 IU/kg), $0.04 \%$ vitamin A premix (291 million IU/kg), 0.65\% Tylan-40 (Elanco Animal Health, Greenfield, IN), and 1\% Rumensin-80 (Elanco Animal Health).

gradeable intake protein increases, urinary $\mathrm{N}$ excretion increases (Cecava and Hancock, 1994; Gueye et al., 2003b; McBride et al., 2003).

Few studies have examined mechanisms that control ammonia emissions from beef cattle feedlots. A greater understanding of the factors controlling $\mathrm{NH}_{3}-\mathrm{N}$ emissions from feedlots would aid in the development of prediction models and in the development of methods to control these emissions. To that end, this study was conducted to determine the effects of dietary CP concentration and degradability on potential $\mathrm{NH}_{3}-\mathrm{N}$ losses from feces and urine of beef cattle fed high-concentrate finishing diets.

\section{Materials and Methods}

\section{Cattle and Diets}

All procedures were approved by the appropriate animal care and use committees at each institution (FASS, 1999). Fifty-four crossbred steers (average initial BW = $315 \mathrm{~kg}$ ) were used in the study. One-half of the steers were located at the USDA-ARS/Texas Agric. Exp. Stn. experimental feedlot at Bushland, TX, and the other half was located at the Texas Tech University Research Center in New Deal. All procedures were the same at both locations. Steers were randomly assigned to one of nine dietary treatments in a $3 \times 3$ factorial arrangement. Main treatment effects were three formulated dietary CP concentrations $(11.5,13$, and $14.5 \%$ on a DM basis) and three supplemental urea:cottonseed meal ratios (100:0, 50:50, and 0:100 of supplemental N; Table 1). With the exception of the protein fraction, all diets were formulated to meet the nutrient requirements for finishing beef steers gaining in excess of 1.6 $\mathrm{kg} / \mathrm{d}$ (NRC, 2000). All diets contained $90 \%$ concentrate and $10 \%$ alfalfa (DM basis) and corn was steam-flaked.
Between urine and fecal collection periods, steers at the USDA/Texas Agric. Exp. Stn. facility were housed in open-lot pens (nine steers per pen) and were individually fed their experimental diets once daily at 0800 in Calan headgates (American Calan, Northwood, NH), whereas steers at Texas Tech University were housed and fed individually in $1.5 \mathrm{~m} \times 2.4 \mathrm{~m}$, soil-surfaced pens. All steers were trained to lead with a halter and adapted to individual tiestalls $(1.2 \mathrm{~m} \times 2.5 \mathrm{~m})$ and urine collection harnesses before the study began.

Three nutrient balance trials were conducted: one near the start $(<30 \mathrm{~d}$ on feed); one near the middle (approximately $75 \mathrm{~d}$ on feed); and one near the end ( $>120 \mathrm{~d}$ on feed) of the feeding period. On the morning that steers were moved to the tiestalls, animals were individually weighed, and blood samples were obtained via jugular venipuncture. Blood was allowed to clot at room temperature, centrifuged, and serum was decanted and frozen. During the feces and urine collection periods at both locations, steers were individually confined in tiestalls and were fitted with urine collection harnesses. Following a 3-d adaptation period, urine and fecal samples for the in vitro $\mathrm{NH}_{3}-\mathrm{N}$ emission studies were obtained during the first 2 to $4 \mathrm{~h}$ of collection on the first day. The $\mathrm{pH}$ of urine was obtained immediately using a combination electrode, and the urine and feces were immediately frozen until used in the ammonia emission study. To determine $\mathrm{N}$ and $\mathrm{P}$ balance, and urine and fecal output, feces and urine were collected separately, weighed, sampled, and composited for an additional 5-d period. Results of the nutrient balance phase of the study are reported elsewhere (Gueye et al., 2003a; McBride et al., 2003).

\section{In Vitro Ammonia Emissions}

The in vitro $\mathrm{NH}_{3}-\mathrm{N}$ emission system has been described (Shi et al., 2001). Briefly, the system was com- 
prised of 48 sealed polyethylene chambers $(20 \mathrm{~cm} \times 20$ $\mathrm{cm} \times 12 \mathrm{~cm}$ deep), each attached to two $\mathrm{NH}_{3}-\mathrm{N}$ trapping bottles containing $100 \mathrm{~mL}$ of $0.9 \mathrm{M}$ sulfuric acid and a vacuum system to pull air through the chambers and $\mathrm{NH}_{3}-\mathrm{N}$ traps at a rate of approximately $3 \mathrm{~L} / \mathrm{min}$. To each chamber was added 1,550 $\mathrm{g}$ (as-is basis) of screened soil (Pullman clay loam) followed by the feces and urine excretion of one steer (two chambers per steer). On average, the soil initially added to the chambers had a $\mathrm{pH}$ of 7.68, was $91.7 \% \mathrm{DM}(\mathrm{SEM}=0.36)$, and contained $0.10 \% \mathrm{~N}(\mathrm{SEM}=0.0011), 1.69 \% \mathrm{C}(\mathrm{SEM}=0.005), 24$ ppm ammonia + ammonium-N $\left(\mathbf{N H}_{\mathbf{x}}-\mathbf{N} ; \mathrm{SEM}=0.06\right)$, and $53 \mathrm{ppm}$ nitrates + nitrites $\left(\mathrm{NO}_{\mathrm{x}}-\mathrm{N} ; \mathrm{SEM}=2.2\right)$ on a DM basis. The quantity of urine and feces added to each chamber was equal to $1 \%$ of the daily excretion by the steer during the nutrient balance trial. Because a total of nine in vitro $\mathrm{NH}_{3}-\mathrm{N}$ runs were required, four chambers containing common feces and urine were included in each run to correct for run-to-run variation in $\mathrm{NH}_{3}-\mathrm{N}$ emissions caused by differences in temperature, atmospheric $\mathrm{NH}_{3}-\mathrm{N}$, air flow rate, or other factors. Two "blank" chambers containing soil but no feces or urine were included in each run to correct for atmospheric $\mathrm{NH}_{3}-\mathrm{N}$ contamination.

Acid traps were replaced with fresh traps each day for $3 \mathrm{~d}$, and then at 2-d intervals until $\mathrm{d} 7$ of collection. At the conclusion of the run, the media in each chamber was thoroughly mixed and a sample was obtained and stored frozen for later laboratory analyses. Chambers were weighed at the start and end of the incubations and $\mathrm{DM}$ and total $\mathrm{N}$ loss were determined by difference.

\section{Laboratory Analyses}

Feces, soil, and media (soil + feces + urine mixture) samples were analyzed for DM by drying to a constant weight at $60^{\circ} \mathrm{C}$ in a forced-draft oven. The $\mathrm{pH}$ of feces, soil, and media were determined by mixing $5 \mathrm{~g}$ of soil or feces with $5 \mathrm{~mL}$ of deionized water. The mixture was stirred, allowed to stand for $1 \mathrm{~min}$, and the $\mathrm{pH}$ determined using a combination electrode. The $\mathrm{C}$ and $\mathrm{N}$ contents of soil, feces, urine, and ending media were determined using a Carbon-Nitrogen Analyzer (Vario Max CN, Elementar Americas, Inc., Mt. Laural, NJ.). The $\mathrm{N}$ content of acid traps was determined colorimetrically using a flow injection analyzer (Lachet Instruments Quick Chem FIA+8000, Milwaukee, WI; Method 10-107-06-2-E, 2001: USEPA [1983] Method 351.2). Initial soil and fecal samples, and ending media samples were extracted with $2 M \mathrm{KCl}(20 \mathrm{~mL} / 2 \mathrm{~g}$ of air-dry sample) and filtered (Whatman No. 42 filter paper). The $\mathrm{NH}_{\mathrm{x}}-\mathrm{N}$ content of the filtrate was determined by the phenate method (Lachat Method 12-107-06-1-A, 2001; USEPA [1983] Method 365.34), and the $\mathrm{NO}_{\mathrm{x}}-\mathrm{N}$ content was determined by $\mathrm{Cd}$ reduction (Lachat Method 12107-04-1-B, 2001; USEPA [1983] Method 353.2) using the flow injection analyzer. Urinary and serum urea-N concentrations were determined colorimetrically using a commercial kit (Sigma Diagnostics, St. Louis, MO; Procedure 640).

\section{Statistical Analyses}

Data were analyzed as a split-plot design with treatments in a $3 \times 3$ factorial arrangement using the GLM procedure of SAS (SAS Inst., Inc., Cary, NC). Factors included in the initial model were location (Bushland or Texas Tech), in vitro ammonia run (1 to 9), fecal collection period (d 30,75 , or 120 on feed), diet combinations, and all two-, three- and four-way interactions. Days on feed, and dietary CP and urea concentration effects were tested using steer nested within diet as the error term. Least squares means, calculated using $\mathrm{NH}_{3}-\mathrm{N}$ run as a covariant, were compared using PDIFF if a significant $(P<0.05) F$-test was obtained. Regressions of $\mathrm{N}$ applications vs. ammonia emitted were determined using the stepwise procedure of PROC REG of SAS.

\section{Results and Discussion}

There were no effects $(P>0.43)$ of cattle location (Bushland vs. Texas Tech) on any variables and no interactions $(P>0.31)$ between in vitro $\mathrm{NH}_{3}-\mathrm{N}$ run and treatments. There were also no interactions $(P>0.22)$ between sampling period (30, 75, or $120 \mathrm{~d}$ ) and dietary treatment or between dietary CP and urea concentration. Therefore, main effects are presented.

\section{Effects of Dietary Protein}

Total daily $\mathrm{N}$ intake and DIP-N intake increased $(P$ $<0.05$ ) as dietary CP concentration increased (Table $2)$. Nitrogen intake was greater $(P<0.05)$ for steers fed the 50:50 urea:cottonseed meal supplement than for steers fed no urea; steers fed the $100 \%$ urea supplement were intermediate. Degradable $\mathrm{N}$ intakes increased $(P$ $<0.05)$ with increasing dietary urea. Serum urea-N concentrations of steers increased with increasing dietary CP concentration. These results agree with previous studies (Johnson and Preston, 1995; Cole et al., 2003). As dietary CP concentration increased from 11.5 to $13 \%$, the quantity of urinary $\mathrm{N}$ excreted increased (data not shown); thus, the quantity of urinary $\mathrm{N}$ added to the chambers increased $(P<0.05)$. The lower urinary $\mathrm{N}$ addition from steers fed the $14.5 \% \mathrm{CP}$ diet than the $13 \%$ CP diet was due in part to lower DMI of steers fed the $14.5 \% \mathrm{CP}$ diet $(6.48 \mathrm{vs} .6 .90 \mathrm{~kg} / \mathrm{d})$, which resulted in similar $\mathrm{N}$ intakes and an apparent shift in $\mathrm{N}$ excretion to the feces. Thus, total $\mathrm{N}$ application, as well as urinary urea $\mathrm{N}$ applications, to the chambers were similar for the 13 and $14.5 \%$ diets and were greater $(P<$ $0.05)$ than for the $11.5 \% \mathrm{CP}$ diet. Fecal N excretions, and thus additions, were greater for the $0 \%$ urea diet than for the 50 or $100 \%$ diets, whereas urinary $\mathrm{N}$ and urinary urea $\mathrm{N}$ excretion and additions increased with increasing dietary urea concentration $(P<0.05)$. 
Table 2. Nutrient intake and serum urea- $\mathrm{N}$ of steers fed the experimental diets and mean quantity of nutrients added to in vitro ammonia emission chambers (overall least squares means for $\mathrm{d} 30,75$, and $120 ; \mathrm{n}=54$ per treatment) ${ }^{\mathrm{a}}$

\begin{tabular}{lcccccccc}
\hline \hline & \multicolumn{3}{c}{ Dietary CP, \% DM } & & \multicolumn{3}{c}{ Urea:cottonseed meal } & \\
\cline { 2 - 3 } Item & 11.5 & 13.0 & 14.5 & & $0: 100^{\mathrm{a}}$ & $50: 50$ & $100: 0$ & SEM \\
\hline $\mathrm{N}$ intake, g/d & $120.2^{\mathrm{b}}$ & $143.3^{\mathrm{c}}$ & $150.4^{\mathrm{d}}$ & & $133.6^{\mathrm{b}}$ & $142.4^{\mathrm{c}}$ & $137.9^{\mathrm{bc}}$ & 1.66 \\
DIP-N intake, g/d & $65.7^{\mathrm{b}}$ & $83.2^{\mathrm{c}}$ & $90.6^{\mathrm{d}}$ & & $71.0^{\mathrm{b}}$ & $82.2^{\mathrm{c}}$ & $86.3^{\mathrm{d}}$ & 1.47 \\
Serum urea-N, mg/100 mL & $7.51^{\mathrm{b}}$ & $9.37^{\mathrm{c}}$ & $11.06^{\mathrm{d}}$ & & 9.20 & 9.57 & 9.13 & 0.17 \\
Feces N added, mg & $382^{\mathrm{b}}$ & $434^{\mathrm{c}}$ & $466^{\mathrm{d}}$ & & $465^{\mathrm{b}}$ & $396^{\mathrm{c}}$ & $422^{\mathrm{c}}$ & 7.40 \\
Urine N added, mg & $459^{\mathrm{b}}$ & $721^{\mathrm{d}}$ & $647^{\mathrm{c}}$ & & $563^{\mathrm{b}}$ & $608^{\mathrm{bc}}$ & $656^{\mathrm{c}}$ & 21.0 \\
Urea-N added, mg & $316^{\mathrm{b}}$ & $571^{\mathrm{c}}$ & $552^{\mathrm{c}}$ & & $424^{\mathrm{b}}$ & $463^{\mathrm{bc}}$ & $553^{\mathrm{c}}$ & 17.3 \\
Urea-N, \% of added N & $34.6^{\mathrm{b}}$ & $46.5^{\mathrm{c}}$ & $48.5^{\mathrm{c}}$ & & $39.8^{\mathrm{b}}$ & $42.4^{\mathrm{bc}}$ & $47.4^{\mathrm{c}}$ & 0.78 \\
Total N added, mg & $840^{\mathrm{b}}$ & $1,155^{\mathrm{c}}$ & $1,113^{\mathrm{c}}$ & & 1,027 & 1,003 & 1,078 & 22.1 \\
\hline
\end{tabular}

${ }^{a}$ Urea:cottonseed meal ratio in protein supplement ( $\mathrm{N}$ basis). DIP-N = ruminally degradable $\mathrm{N}$.

${ }_{\mathrm{b}, \mathrm{c}, \mathrm{d}}$ Means in same row and main treatment comparison without a common superscript letter differ, $P<$ 0.05 .

The chemical composition of feces and urine added to each chamber were affected by diet (Table 3). Fecal $\mathrm{N}$ concentration and urinary $\mathrm{N}, \mathrm{C}$, and urea-N concentration increased $(P<0.05)$ as dietary $\mathrm{CP}$ concentration increased. Urea-N comprised from 67 to $91 \%$ of total urinary N. These values agree with Petersen et al. (1998), who noted that 64 to $94 \%$ of urinary N was urea. Similarly, Smits et al. (1995) noted a $42 \%$ increase in urinary urea concentration when the $\mathrm{CP}$ concentration of lactating dairy cow diets increased from 14.4 to $19.8 \%$. The $\mathrm{pH}$ of feces from steers fed the $11.5 \% \mathrm{CP}$ diet was lower $(P<0.05)$ than for steers fed the 13 and $14.5 \%$ diets. This could have been due to differences in the quantity of starch entering the lower gut for fermentation and/or to differences in dietary calcium carbonate concentrations. Fecal $\mathrm{C}$ and $\mathrm{NH}_{\mathrm{x}} \mathrm{-N}$ and urinary $\mathrm{pH}$ were not affected by dietary $\mathrm{CP}$ concentration. In contrast to our results, Tomlinson et al. (1996) noted that fecal $\mathrm{NH}_{\mathrm{x}}-\mathrm{N}$ concentration increased as dietary $\mathrm{CP}$ concentration increased in dairy cows. However, in agreement with our results, Tomlinson et al. (1996) noted an increase in fecal $\mathrm{N}$, urinary total $\mathrm{N}$, and uri- nary urea-N concentration as dietary $\mathrm{CP}$ concentration increased.

The percentage of supplemental urea also affected feces and urine composition. Fecal $\mathrm{N}$ concentration was greater for steers fed the $0 \%$ urea diet than for those fed the 50 or $100 \%$ urea supplements. Urinary N, C, and urea- $\mathrm{N}$ concentrations increased with increasing dietary urea percentage. Fecal $\mathrm{C}$ and $\mathrm{NH}_{\mathrm{x}}-\mathrm{N}$ and urinary $\mathrm{pH}$ were not affected by dietary percentage of urea. These results tend to disagree with those of Tomlinson et al. (1996), who noted that fecal $\mathrm{NH}_{\mathrm{x}}-\mathrm{N}$ concentration decreased as ruminal degradability of the dietary $\mathrm{CP}$ increased.

The quantity of $\mathrm{NH}_{3}-\mathrm{N}$ lost over the 7-d in vitro incubation period, in vitro $\mathrm{NH}_{3}-\mathrm{N}$ losses as a percentage of urinary $\mathrm{N}$ applied, and total in vitro $\mathrm{N}$ losses (determined by difference) were greater $(P<0.05)$ from steers fed the 13 and $14.5 \% \mathrm{CP}$ diets than from steers fed the $11.5 \% \mathrm{CP}$ diet (Table 4). However, total in vitro $\mathrm{N}$ lost as a percentage of urinary $\mathrm{N}$ applied was greater $(P<$ 0.05 ) for the $11.5 \% \mathrm{CP}$ diet than the 13 and $14.5 \% \mathrm{CP}$ diets. This tends to contrast with results of Paul et

Table 3. Chemical characteristics of feces and urine added to chambers (overall least squares means for $\mathrm{d} 30,75$, and $120 ; \mathrm{n}=54$ per treatment)

\begin{tabular}{|c|c|c|c|c|c|c|c|}
\hline \multirow[b]{2}{*}{ Item } & \multicolumn{3}{|c|}{ Dietary CP, \% DM } & \multicolumn{3}{|c|}{ Urea:cottonseed meal ${ }^{\mathrm{a}}$} & \multirow[b]{2}{*}{ SEM } \\
\hline & 11.5 & 13.0 & 14.5 & $0: 100^{\mathrm{a}}$ & $50: 50$ & $100: 0$ & \\
\hline Feces $\mathrm{N}, \% \mathrm{DM}$ & $3.11^{b}$ & $3.20^{\mathrm{bc}}$ & $3.29^{\mathrm{c}}$ & $3.30^{\mathrm{b}}$ & $3.16^{\mathrm{c}}$ & $3.14^{\mathrm{c}}$ & 0.02 \\
\hline Feces C, \% DM & 47.4 & 47.1 & 47.3 & 47.5 & 47.0 & 47.4 & 0.10 \\
\hline $\begin{array}{l}\text { Feces, } \mathrm{NH}_{\mathrm{x}}-\mathrm{N}, \mathrm{ppm} \\
\text { of } \mathrm{DM}^{\mathrm{d}}\end{array}$ & 1,172 & 1,224 & 1,234 & 1,173 & 1,218 & 1,230 & 43.3 \\
\hline Feces pH & $6.21^{\mathrm{b}}$ & $6.53^{\mathrm{c}}$ & $6.50^{\mathrm{c}}$ & 6.49 & 6.44 & 6.31 & 0.039 \\
\hline Urine $\mathrm{N}$, ppm & $8,917^{\mathrm{b}}$ & $11,094^{\mathrm{c}}$ & $11,754^{\mathrm{c}}$ & $9,883^{\mathrm{b}}$ & $10,406^{\mathrm{bc}}$ & $11,399^{\mathrm{c}}$ & 281 \\
\hline Urine $\mathrm{C}$, ppm & $3,834^{\mathrm{b}}$ & $4,769^{\mathrm{c}}$ & $5,054^{\mathrm{c}}$ & $4,249^{\mathrm{b}}$ & $4,474^{\mathrm{c}}$ & $4,933^{\mathrm{c}}$ & 121 \\
\hline Urine $\mathrm{pH}$ & 7.66 & 7.60 & 7.57 & 7.59 & 7.64 & 7.64 & 0.06 \\
\hline Urea-N, \% urine $\mathrm{N}$ & $70.2^{\mathrm{b}}$ & $80.3^{\mathrm{c}}$ & $87.2^{\mathrm{d}}$ & $67.6^{\mathrm{b}}$ & $79.3^{\mathrm{c}}$ & $90.8^{\mathrm{d}}$ & 1.23 \\
\hline
\end{tabular}

\footnotetext{
${ }^{\mathrm{a}}$ Urea:cottonseed meal ratio in protein supplement ( $\mathrm{N}$ basis).

${ }^{\mathrm{b}, \mathrm{c}}$ Means in same row and main treatment comparison without a common superscript letter differ, $P<$ 0.05 .

${ }^{\mathrm{d}} \mathrm{NH}_{\mathrm{x}}-\mathrm{N}=$ ammonia + ammonium-N.
} 
Table 4. Cumulative ammonia $\mathrm{N}$ emitted and total $\mathrm{N}$, DM, and $\mathrm{C}$ losses over $7 \mathrm{~d}$ from in vitro chambers (overall least squares means of $d 30,75$, and 120; $n=54$ per treatment)

\begin{tabular}{|c|c|c|c|c|c|c|c|}
\hline \multirow[b]{2}{*}{ Item } & \multicolumn{3}{|c|}{ Dietary CP, \% DM } & \multicolumn{3}{|c|}{ Urea:cottonseed meal $^{\mathrm{a}}$} & \multirow[b]{2}{*}{ SEM } \\
\hline & 11.5 & 13.0 & 14.5 & $0: 100^{\mathrm{a}}$ & $50: 50$ & $100: 0$ & \\
\hline $\mathrm{NH}_{3}-\mathrm{N}$ lost, mg & $17.55^{\mathrm{b}}$ & $35.09^{c}$ & $29.41^{\mathrm{d}}$ & $23.99^{\mathrm{b}}$ & $26.38^{\mathrm{c}}$ & $31.67^{\mathrm{d}}$ & 1.45 \\
\hline $\begin{array}{l}\mathrm{NH}_{3}-\mathrm{N} \text { lost, \% of } \\
\text { urine } \mathrm{N} \text { applied }\end{array}$ & $3.15^{\mathrm{b}}$ & $4.34^{\mathrm{c}}$ & $4.32^{\mathrm{c}}$ & 3.87 & 3.84 & 4.07 & 0.11 \\
\hline Total N lost, mg & $136.7^{\mathrm{b}}$ & $178.4^{\mathrm{c}}$ & $165.8^{\mathrm{c}}$ & 167.0 & 147.8 & 166.0 & 10.4 \\
\hline $\mathrm{N}$ lost, $\%$ of added $\mathrm{N}$ & 15.6 & 14.6 & 14.1 & 15.7 & 13.6 & 15.0 & 0.88 \\
\hline $\mathrm{N}$ lost, \% urine $\mathrm{N}$ & $37.3^{\mathrm{b}}$ & $25.9^{c}$ & $27.0^{\mathrm{c}}$ & 33.1 & 26.1 & 31.1 & 2.14 \\
\hline $\mathrm{NH}_{3}-\mathrm{N}, \% \mathrm{~N}$ lost & 44.6 & 43.1 & 42.0 & 42.0 & 45.4 & 42.2 & 2.17 \\
\hline DM loss \% & $0.93^{\mathrm{b}}$ & $1.35^{\mathrm{bc}}$ & $1.84^{\mathrm{c}}$ & 1.34 & 1.32 & 1.43 & 0.16 \\
\hline C loss, mg & 2,094 & 1,632 & 2,010 & $2,104^{\mathrm{bc}}$ & $1,399^{c}$ & $2,237^{\mathrm{b}}$ & 188 \\
\hline $\mathrm{C}$ loss, $\%$ & 6.57 & 4.72 & 5.89 & 6.33 & 4.28 & 6.59 & 0.59 \\
\hline
\end{tabular}

al. (1998) using dairy cattle slurry. They noted a $40 \%$ decrease in 48-h in vitro $\mathrm{NH}_{3}-\mathrm{N}$ losses when dietary $\mathrm{CP}$ was decreased from 16.4 to $12.3 \%$ in one trial, and a $20 \%$ decrease in $\mathrm{NH}_{3}-\mathrm{N}$ loss when dietary $\mathrm{CP}$ was decreased from 18.3 to $15.3 \%$ in a second trial. In their study, the lower in vitro $\mathrm{NH}_{3}-\mathrm{N}$ production was caused by both a decrease in the amount of $\mathrm{N}$ excreted as well as a decrease in the proportion of excreted $\mathrm{N}$ that volatilized. The somewhat lower in vitro $\mathrm{NH}_{3}-\mathrm{N}$ emissions from urine + feces of steers fed the $14.5 \% \mathrm{CP}$ diet than from steers fed the $13 \% \mathrm{CP}$ diet was unexpected because a greater proportion of urinary $\mathrm{N}$ was from urea on the $14.5 \%$ diet. However, portions of the nonurea $\mathrm{N}$ in urine could have been $\mathrm{NH}_{\mathrm{x}}-\mathrm{N}$, which could volatilize rapidly. The $\mathrm{pH}$ of feces, urine, and soil did not differ (Table 3) and thus should not have affected $\mathrm{NH}_{3}-\mathrm{N}$ volatilization. Whitehead et al. (1989) reported that hippuric acid content could significantly affect $\mathrm{NH}_{3}$ $\mathrm{N}$ volatilization losses from artificial urines. Adding hippuric acid to a urea solution similar to urine increased $\mathrm{NH}_{3}-\mathrm{N}$ losses by 5 to 10 times. Thus, unmeasured factors such as hippuric acid content might explain the lack of large differences in ammonia losses between the 13 and $14.5 \%$ diets.

Total in vitro $\mathrm{N}$ lost as a percentage of $\mathrm{N}$ (feces + urine) added to the chambers, $\mathrm{NH}_{3}-\mathrm{N}$ lost as a percentage of total in vitro $\mathrm{N}$ lost, and $\mathrm{C}$ lost were not affected by diet; however, in vitro DM loss increased with increasing dietary CP concentration. The reason for this increase is not clear. On average, in vitro $\mathrm{NH}_{3}-\mathrm{N}$ loss accounted for $43.1 \pm 2.17 \%$ of the total $\mathrm{N}$ loss. Thus, approximately $57 \%$ of $\mathrm{N}$ losses may have occurred as dinitrogen gases, amines, or other $\mathrm{N}$-containing gases. Harper et al. (2000) noted that considerable quantities of $\mathrm{N}$ volatilized from swine waste lagoons as dinitrogen gas rather than as $\mathrm{NH}_{3}-\mathrm{N}$. Using soil columns treated with urine, Stewart (1970) reported that 2 to $40 \%$ of urinary $\mathrm{N}$ was lost as $\mathrm{NO}_{\mathrm{x}}-\mathrm{N}$ in the soil. Koops et al. (1997) noted that approximately $2.2 \%$ of urinary $\mathrm{N}$ ex- creted onto pastures was lost as nitrous oxide through nitrification and denitrification.

Cumulative 7-d in vitro $\mathrm{NH}_{3}-\mathrm{N}$ losses increased $(P<$ $0.05)$ with increasing dietary urea concentration. In vitro $\mathrm{C}$ losses were less $(P<0.05)$ from the $50 \%$ urea than from the $100 \%$ urea supplement diets; however, the reason for this difference is not apparent. No other factors were affected by dietary urea concentration.

A relatively small percentage of the urinary $\mathrm{N}$ added to the chambers was actually lost as $\mathrm{NH}_{3}-\mathrm{N}(3.90 \pm$ $0.11 \%)$. This finding tends to contrast with the results of Stewart (1970), who noted that 25 to $90 \%$ of urinary $\mathrm{N}$ additions to soil columns were lost as $\mathrm{NH}_{3}-\mathrm{N}$. Similarly, a number of studies of urine additions to pastures and slurry additions to cropland suggest urinary $\mathrm{N}$ losses as $\mathrm{NH}_{3}-\mathrm{N}$ in the range of 4 to $50 \%$ of $\mathrm{N}$ applied (Ryden et al., 1987; Jarvis et al., 1989, Lockyer and Whitehead, 1990). Kellems et al. (1979) noted that more than $95 \%$ of urinary $\mathrm{N}$ was volatilized as $\mathrm{NH}_{3}-\mathrm{N}$ from cattle manure slurries. However, Kellems et al. (1979) did not use any soil in their incubation flasks; therefore, the medium used was probably not representative of a typical feedlot surface. Using micrometeorology methods, Hutchinson et al. (1982) reported that hourly $\mathrm{NH}_{3}$ $\mathrm{N}$ losses from a Colorado feed yard ranged from 0.64 to $2.37 \mathrm{~kg}$ of $\mathrm{N} / \mathrm{ha}$. This amounted to approximately $50 \%$ of urinary $\mathrm{N}$ excretion or $25 \%$ of total $\mathrm{N}$ excretion (approximately $20 \%$ of $\mathrm{N}$ fed). Using a total $\mathrm{N}$ balance method, Erickson and Klopfenstein (2001a,b) reported that total $\mathrm{N}$ volatilization losses from a Nebraska experimental feedlot were 40 to $50 \%$ of $\mathrm{N}$ intake during the winter and $60 \%$ of $\mathrm{N}$ intake during the summer. The large differences in values between Hutchinson et al. (1982) and Erickson and Klopfenstein (2001a,b) could be accounted for by losses of dinitrogen gas (Kumar and Aggarwal, 1998; Harper et al., 2000).

These large variations in apparent gaseous $\mathrm{NH}_{3}-\mathrm{N}$ losses are probably due to a number of factors including the methodology used, turnover rate of air in chambers, 
Table 5. Chemical composition of media at conclusion of a 7-d in vitro ammonia emission run (overall least squares means of $d 30,75$, and $120 ; n=54$ per treatment)

\begin{tabular}{|c|c|c|c|c|c|c|c|}
\hline \multirow[b]{2}{*}{ Item } & \multicolumn{3}{|c|}{ Dietary CP, \% DM } & \multicolumn{3}{|c|}{ Urea:cottonseed meal $^{\mathrm{a}}$} & \multirow[b]{2}{*}{ SEM } \\
\hline & 11.5 & 13.0 & 14.5 & $0: 100^{\mathrm{a}}$ & $50: 50$ & $100: 0$ & \\
\hline Ending $\mathrm{pH}$ & 8.00 & 8.01 & 8.01 & 8.02 & 8.01 & 7.99 & 0.01 \\
\hline $\begin{array}{l}\text { Ending } \mathrm{NH}_{\mathrm{x}}-\mathrm{N}, \mathrm{ppm} \\
\text { of } \mathrm{DM}^{\mathrm{d}}\end{array}$ & $233^{\mathrm{b}}$ & $362^{\mathrm{c}}$ & $350^{\mathrm{c}}$ & $290^{\mathrm{b}}$ & $311^{\mathrm{bc}}$ & $345^{\mathrm{c}}$ & 10.2 \\
\hline $\mathrm{NH}_{\mathrm{x}}-\mathrm{N}$ total, $\mathrm{mg}$ & $346^{\mathrm{b}}$ & $547^{\mathrm{c}}$ & $523^{\mathrm{c}}$ & $434^{\mathrm{b}}$ & $463^{\mathrm{b}}$ & $520^{\mathrm{c}}$ & 15.7 \\
\hline $\begin{array}{l}\mathrm{NH}_{\mathrm{x}}-\mathrm{N}, \% \text { total } \mathrm{N} \\
\text { Ending } \mathrm{NO}_{\mathrm{x}}-\mathrm{N}, \mathrm{ppm}\end{array}$ & $14.1^{\mathrm{b}}$ & $20.0^{\mathrm{c}}$ & $19.6^{\mathrm{c}}$ & $17.0^{\mathrm{b}}$ & $17.8^{\mathrm{b}}$ & $19.4^{\mathrm{c}}$ & 0.51 \\
\hline $\mathrm{DM}$ & 53.8 & 53.9 & 57.6 & 54.0 & 54.6 & 56.6 & 1.32 \\
\hline $\begin{array}{l}\mathrm{NO}_{\mathrm{x}}-\mathrm{N}, \% \text { total } \mathrm{N} \\
\text { Media } \mathrm{NH}_{\mathrm{x}} \text { :gaseous }\end{array}$ & 3.51 & 3.21 & 3.40 & 3.35 & 3.33 & 3.45 & 0.08 \\
\hline $\mathrm{NH}_{3}$ ratio & $31.7^{\mathrm{b}}$ & $22.1^{\mathrm{c}}$ & $22.4^{\mathrm{c}}$ & 26.1 & 26.1 & 24.0 & 1.00 \\
\hline
\end{tabular}

atmospheric environment, and soil characteristics. Several studies have demonstrated that $\mathrm{NH}_{3}-\mathrm{N}$ emissions measured using chambers or wind tunnels increase linearly as air turnover rate increases up to a maximum of 15 turnovers/min (Kissel et al., 1977; Whitehead and Raistrick, 1991). In our study, the flow rate used was approximately 1.2 turnovers per min. Thus, although relative comparisons of $\mathrm{NH}_{3}-\mathrm{N}$ losses from different treatments should be valid, the actual quantities emitted will be lower than would be noted under normal feedlot conditions.

Ammonia + ammonium-N concentrations in ending media were greater in the 13 and $14.5 \% \mathrm{CP}$ diets than in the $11.5 \% \mathrm{CP}$ diet (Table 5). On average, the ratio of $\mathrm{NH}_{\mathrm{x}}-\mathrm{N}$ in the media to gaseous $\mathrm{NH}_{3}-\mathrm{N}$ losses was greater $(P<0.05)$ for the $11.5 \% \mathrm{CP}$ diet than the 13 and $14.5 \% \mathrm{CP}$ diets. Ammonia + ammonium-N concentrations and the total quantity of $\mathrm{NH}_{\mathrm{x}}-\mathrm{N}$ also increased with increasing dietary urea $(P<0.05)$. The $\mathrm{pH}$ of the ending media was high enough so that it should not have prevented conversion of soil $\mathrm{NH}_{4}-\mathrm{N}$ to the more volatile $\mathrm{NH}_{3}-\mathrm{N}$. Thus, the accumulation of $\mathrm{NH}_{\mathrm{x}}-\mathrm{N}$ in the soil may have been due to other factors including high soil cation exchange capacity or low soil moisture (Fenn and Kissel, 1976). Concentrations of $\mathrm{NO}_{\mathrm{x}}-\mathrm{N}$ in the ending media were not affected by diet and were similar to initial soil concentrations (53 ppm); thus, little if any of the added $\mathrm{N}$ accumulated as $\mathrm{NO}_{\mathrm{x}}-\mathrm{Nin}$ the soil. In the present study, the cumulative quantity of $\mathrm{NH}_{\mathrm{x}}-\mathrm{N}$ was $77.4 \pm 1.23 \%$ of urinary- $\mathrm{N}$ applied and $99.7 \pm 1.43 \%$ of urinary urea- $\mathrm{N}$ applied, whereas $\mathrm{NO}_{\mathrm{x}}{ }^{-}$ $\mathrm{N}$ represented less than $4 \%$ of applied $\mathrm{N}$. In contrast, using soil columns and periodic additions of urine, Stewart (1970) reported that up to $40 \%$ of urinary N applied accumulated as $\mathrm{NO}_{\mathrm{x}}-\mathrm{N}$ in the soil column. Thompson and Fillery (1998) noted that up to $65 \%$ of urea-N applied to grass pastures was accounted for in soil $\mathrm{NO}_{\mathrm{x}}-\mathrm{N}$ and 0.2 to $49 \%$ was as soil $\mathrm{NH}_{\mathrm{x}}-\mathrm{N}$. In the studies of Stewart (1970) and Thompson and Fillery
(1998), no feces or other source of ureolytic bacteria was added to the soil. With added feces, there may be a more rapid hydrolysis of urea to $\mathrm{NH}_{4}-\mathrm{N}$ as well as a more rapid uptake of $\mathrm{NH}_{\mathrm{x}}-\mathrm{N}$ by fecal bacteria. Thus, less $\mathrm{NO}_{\mathrm{x}}-\mathrm{N}$ might accumulate. In addition, the difference in soil depth (30 vs. $2.5 \mathrm{~cm}$; Fenn and Kissel, 1976) and moisture content (Catchpoole et al., 1983; Pandrangi et al., 2003) of the Stewart (1970) soil and our soil may have also been factors. However, the ending media moisture concentration in this trial was similar to that in samples from actual feedyard surfaces (Mason, 2004).

\section{Effects of Days on Feed}

Characteristics of steers during each sampling period are presented in Table 6. As days on feed increased, serum urea-N increased $(P<0.05)$; however, total $\mathrm{N}$

Table 6. Mean nutrient intake by steers and mean quantity of nutrients added to in vitro ammonia emission chambers at each sampling period (overall least squares means; $\mathrm{n}=$ 54 per day)

\begin{tabular}{lcccc}
\hline \hline & \multicolumn{3}{c}{ Collection period (days on feed) } & \\
\cline { 2 - 4 } Item & $<30^{\mathrm{a}}$ & 75 & $>120$ & SEM \\
\hline BW, kg & $363.4^{\mathrm{b}}$ & $447.9^{\mathrm{c}}$ & $513.6^{\mathrm{d}}$ & 3.79 \\
$\mathrm{~N}$ intake, g/d & 140.4 & 138.6 & 135.1 & 1.24 \\
DIP-N intake, g/d & 81.7 & 80.0 & 77.8 & 0.96 \\
Serum urea-N, mg/100 mL & $6.62^{\mathrm{b}}$ & $8.84^{\mathrm{c}}$ & $12.48^{\mathrm{d}}$ & 0.17 \\
Feces N added, mg & $422^{\mathrm{bc}}$ & $462^{\mathrm{c}}$ & $399^{\mathrm{b}}$ & 7.4 \\
Urine N added, mg & $430^{\mathrm{b}}$ & $647^{\mathrm{c}}$ & $740^{\mathrm{d}}$ & 21.0 \\
Urea-N added, mg & $304^{\mathrm{b}}$ & $510^{\mathrm{c}}$ & $604^{\mathrm{d}}$ & 17.3 \\
Urea-N, \% of added N & $35.7^{\mathrm{b}}$ & $46.1^{\mathrm{c}}$ & $53.0^{\mathrm{d}}$ & 0.78 \\
Total N added, mg & $852^{\mathrm{b}}$ & $1,109^{\mathrm{c}}$ & $1,139^{\mathrm{d}}$ & 22.1 \\
\hline
\end{tabular}

${ }^{a}$ Approximate days on feed when feces and urine were collected. DIP-N = ruminally degradable $\mathrm{N}$.

b,c,d Means in same row without a common superscript letter differ, $P<0.05$. 
Table 7. Chemical composition of feces and urine added during each collection period (overall least squares means; $\mathrm{n}=54$ per day)

\begin{tabular}{lcccc}
\hline \hline & \multicolumn{3}{c}{ Collection period (days on feed) } & \\
\cline { 2 - 4 } Item & $<30^{\mathrm{a}}$ & 75 & $>120$ & SEM \\
\hline Feces N, \% DM & 3.25 & 3.18 & 3.18 & 0.02 \\
Feces C, \% DM & 48.0 & 47.6 & 46.3 & 0.11 \\
Feces NH $-\mathrm{N}, \mathrm{ppm}$ of $\mathrm{DM}^{\mathrm{e}}$ & 1,217 & 1,191 & 1,218 & 43.4 \\
Feces pH & 6.55 & 6.45 & 6.24 & 0.039 \\
Urine N, mg/kg & $6,872^{\mathrm{b}}$ & $11,993^{\mathrm{c}}$ & $12,735^{\mathrm{d}}$ & 281 \\
Urine C, mg/kg & $2,955^{\mathrm{b}}$ & $5,167^{\mathrm{c}}$ & $5,476^{\mathrm{d}}$ & 121 \\
Urine pH & 7.73 & 7.50 & 7.63 & 0.055 \\
Urea-N, \% urine N & $73.6^{\mathrm{b}}$ & $78.0^{\mathrm{c}}$ & $84.6^{\mathrm{d}}$ & 1.23 \\
\hline
\end{tabular}

${ }^{a}$ Approximate days on feed when feces and urine were collected.

b,c,d Means in same row without a common superscript letter differ, $P<0.05$.

${ }^{\mathrm{e}} \mathrm{NH}_{\mathrm{x}}-\mathrm{N}$ = ammonia + ammonium-N.

intake and DIP-N intake were not affected. The quantity of feces $\mathrm{N}$ added to the chambers was greater on $\mathrm{d}$ 75 than on $\mathrm{d} 120$, with $\mathrm{d} 30$ being intermediate. Nonetheless, the quantity of urinary $\mathrm{N}$, urinary urea-N, and total $\mathrm{N}$ added to the chambers and proportion of added $\mathrm{N}$ that was urea-N increased with days on feed $(P<$ $0.05)$. The relatively high $(12.4 \mathrm{mg} / 100 \mathrm{~mL})$ serum urea $\mathrm{N}$ concentrations of steers during the sampling period at $120 \mathrm{~d}$ on feed suggest that $\mathrm{CP}$ was being fed in excess of requirements (Johnson and Preston, 1995; Cole et al., 2003).

Days on feed did not affect fecal $\mathrm{N}, \mathrm{C}$, or $\mathrm{NH}_{\mathrm{x}}-\mathrm{N}$ concentration, or fecal and urine $\mathrm{pH}$ (Table 7). Urinary $\mathrm{N}, \mathrm{C}$, and urea-N concentrations increased $(P<0.05)$ with days on feed. Cumulative in vitro $\mathrm{NH}_{3}-\mathrm{N}$ losses, total $\mathrm{N}$ losses, and $\mathrm{C}$ losses increased as days on feed increased (Table $8 ; P<0.05$ ). This was apparently due to both greater urinary $\mathrm{N}$ applications as well as a greater proportion of urinary $\mathrm{N}$ being lost as $\mathrm{NH}_{3}-\mathrm{N}(P$ $<0.01$ ) as days on feed increased. As noted earlier, this is potentially due to differences in other metabolites such as hippuric acid in the urine. As steers approach their market or mature weight, protein deposition decreases (NRC, 2000). Thus, if CP intake remains the same as animals increase in BW, as it did in this study, the proportion and quantity of dietary $\mathrm{N}$ excreted in the urine and the proportion of urinary $\mathrm{N}$ that is urea$\mathrm{N}$ increase. This potentially leads to increased $\mathrm{NH}_{3}-\mathrm{N}$ emissions. Ammonia-N losses accounted for less $(P<$ 0.05 ) of the total $\mathrm{N}$ loss on $\mathrm{d} 30$ than on $\mathrm{d} 75$ and 120. Total in vitro DM and $\mathrm{C}$ losses also increased $(P<0.05)$ with days on feed. The exact reason for these differences is not apparent, but it could relate to both the quantity of urea hydrolyzed and to the quantity and form of carbohydrates that were present in the feces added to the chambers.

The $\mathrm{pH}$ of the ending media, the concentration of $\mathrm{NH}_{\mathrm{x}}-\mathrm{N}$ in the ending media, and the percentage of urinary $\mathrm{N}$ lost as $\mathrm{NH}_{\mathrm{x}}-\mathrm{N}$ increased as days on feed increased $\left(P<0.05\right.$; Table 9). However, the soil $\mathrm{NH}_{\mathrm{x}}{ }^{-}$ $\mathrm{N}$ :gaseous $\mathrm{NH}_{3}-\mathrm{N}$ ratio decreased with days on feed ( $P$ $<0.05)$. This may have been due in part to the differences in $\mathrm{pH}$. As the $\mathrm{pH}$ increases, a greater proportion of the $\mathrm{NH}_{4}-\mathrm{N}$ formed from hydrolysis of urinary urea could escape as $\mathrm{NH}_{3}-\mathrm{N}$. Media $\mathrm{NH}_{\mathrm{x}}-\mathrm{N}$, as a percentage of total media $\mathrm{N}$, increased $(P<0.05)$ with increasing days on feed. Nitrate concentrations in the ending media were not affected by days on feed.

Table 8. Cumulative ammonia-N, N, dry matter, and C losses during the 7-d in vitro incubation period (overall least squares means; $\mathrm{n}=54$ per day)

\begin{tabular}{lcccc}
\hline \hline & \multicolumn{3}{c}{ Collection period (days on feed) } \\
\cline { 2 - 4 } Item & $<30^{\mathrm{a}}$ & 75 & $>120$ & SEM \\
\hline $\mathrm{NH}_{3}$-N lost, mg & $13.26^{\mathrm{b}}$ & $26.66^{\mathrm{c}}$ & $41.04^{\mathrm{d}}$ & 1.19 \\
$\mathrm{NH}_{3}$-N lost, \% of urine N & $2.76^{\mathrm{b}}$ & $3.82^{\mathrm{c}}$ & $5.60^{\mathrm{d}}$ & 0.11 \\
Total N lost, mg & $137.8^{\mathrm{b}}$ & $161.2^{\mathrm{bc}}$ & $177.6^{\mathrm{c}}$ & 10.4 \\
$\mathrm{~N}$ lost, \% added N & 15.3 & 13.2 & 15.6 & 0.88 \\
$\mathrm{~N} \mathrm{lost,} \mathrm{\%} \mathrm{urine} \mathrm{N}_{\mathrm{NH}}$-N lost, \% N lost & $37.6^{\mathrm{b}}$ & 25.0 & 27.7 & 2.14 \\
DM loss, \% & $38.1^{\mathrm{b}}$ & $46.3^{\mathrm{c}}$ & $45.0^{\mathrm{c}}$ & 2.17 \\
$\mathrm{C}$ loss, mg & $0.18^{\mathrm{b}}$ & $0.80^{\mathrm{c}}$ & $3.10^{\mathrm{d}}$ & 0.16 \\
$\mathrm{C}$ loss, \% & $604^{\mathrm{b}}$ & $1,128^{\mathrm{b}}$ & $4,152^{\mathrm{c}}$ & 189 \\
\hline
\end{tabular}

${ }^{a}$ Approximate days on feed when feces and urine were collected.

b,c,d Means in same row without a common superscript letter differ, $P<0.05$. 
Table 9. Chemical composition of media at the conclusion of 7-d incubation period (overall least squares means; $\mathrm{n}=54$ per day)

\begin{tabular}{|c|c|c|c|c|}
\hline \multirow[b]{2}{*}{ Item } & \multicolumn{3}{|c|}{ Collection period (days on feed) } & \multirow[b]{2}{*}{ SEM } \\
\hline & $<30^{\mathrm{a}}$ & 75 & $>120$ & \\
\hline Ending $\mathrm{pH}$ & $7.84^{\mathrm{b}}$ & $8.01^{\mathrm{c}}$ & $8.18^{\mathrm{d}}$ & 0.008 \\
\hline Ending $\mathrm{NH}_{\mathrm{x}}-\mathrm{N}, \mathrm{ppm} \mathrm{DM}^{\mathrm{e}}$ & $208^{\mathrm{b}}$ & $341^{\mathrm{c}}$ & $389^{\mathrm{d}}$ & 10.2 \\
\hline $\mathrm{NH}_{\mathrm{x}}-\mathrm{N}, \mathrm{mg}$ & $308^{\mathrm{b}}$ & $506^{\mathrm{c}}$ & $591^{\mathrm{d}}$ & 15.7 \\
\hline $\mathrm{NH}_{\mathrm{x}}-\mathrm{N}, \%$ total $\mathrm{N}$ & $12.3^{\mathrm{b}}$ & $19.6^{\mathrm{c}}$ & $22.1^{\mathrm{d}}$ & 0.52 \\
\hline $\mathrm{NH}_{\mathrm{x}}-\mathrm{N}, \%$ of urine- $\mathrm{N}$ added & $71.6^{\mathrm{b}}$ & $78.2^{\mathrm{c}}$ & $80.0^{c}$ & 1.23 \\
\hline $\mathrm{NH}_{\mathrm{x}}-\mathrm{N}, \%$ of urea- $\mathrm{N}$ added & 101.3 & 99.2 & 97.9 & 1.43 \\
\hline $\mathrm{NH}_{\mathrm{x}}-\mathrm{N}, \%$ total $\mathrm{N}$ & $12.3^{\mathrm{b}}$ & $19.6^{\mathrm{c}}$ & $22.1^{\mathrm{d}}$ & 0.47 \\
\hline Media $\mathrm{NH}_{\mathrm{x}}$ :gaseous $\mathrm{NH}_{3}$ ratio & $32.6^{\mathrm{d}}$ & $26.0^{\mathrm{c}}$ & $17.3^{\mathrm{b}}$ & 1.8 \\
\hline Ending $\mathrm{NO}_{\mathrm{x}}-\mathrm{N}, \mathrm{ppm} \mathrm{DM}$ & 71.5 & 41.3 & 53.3 & 12.6 \\
\hline $\mathrm{NO}_{\mathrm{x}}-\mathrm{N}, \%$ total $\mathrm{N}$ & 4.35 & 2.52 & 3.33 & 0.48 \\
\hline
\end{tabular}

${ }^{a}$ Approximate days on feed when feces and urine were collected.

b,c,d Means in same row without a common superscript letter differ, $P<0.05$.

${ }^{\mathrm{e}} \mathrm{NH}_{\mathrm{x}}-\mathrm{N}=$ ammonia + ammonium-N.

\section{Regression Analyses}

For the three sampling periods, the overall regression equation for the relationship between urinary $\mathrm{N}$ applied (mg) and in vitro $\mathrm{NH}_{3}-\mathrm{N}$ emissions $(\mathrm{mg})$ after $7 \mathrm{~d}$ is presented in Table 10. There was no apparent correlation between fecal $\mathrm{N}$ applied and in vitro $\mathrm{NH}_{3}-\mathrm{N}$ losses $\left(\mathrm{r}^{2}<0.01\right)$. Petersen et al. (1998) also noted minimal $\mathrm{NH}_{3}-\mathrm{N}$ losses from dung pats on pastures, whereas 3 to $52 \%$ of urinary $\mathrm{N}$ was lost as $\mathrm{NH}_{3}-\mathrm{N}$. With feces and urine from dairy cows, Paul et al. (1998) reported that the primary source of $\mathrm{NH}_{3}-\mathrm{N}$ emission was the urine fraction. Ammonia-N losses in their study were 0.33 $\mathrm{mg}$ of $\mathrm{NH}_{3}-\mathrm{N} / \mathrm{kg}$ of wet feces and $4.99 \mathrm{mg}$ of $\mathrm{NH}_{3}-\mathrm{N} / \mathrm{kg}$ of urine. Obviously, the quantity of urinary $\mathrm{N}$ excreted had a major effect on in vitro gaseous $\mathrm{NH}_{3}-\mathrm{N}$ emissions in the present study; however, other factors also had a major effect, accounting for at least $31 \%$ of the variation in $\mathrm{NH}_{3}-\mathrm{N}$ losses. Regressions determined for the individual sampling periods indicated that as the days on feed increased, the slope of the regression equation increased (Table 10). Ammonia-N emission was also highly correlated with urinary urea-N application, although the $\mathrm{r}^{2}$ value tended to be lower (0.58) than for total urinary $\mathrm{N}$ application. This would be expected because urinary urea- $\mathrm{N}$ concentrations were correlated $\left(\mathrm{r}^{2}=0.20 ; P<0.001\right)$ to total urinary $\mathrm{N}$.

Ideally, $\mathrm{NH}_{3}-\mathrm{N}$ emissions from CAFO could be calculated using models based on dietary, animal, and environmental factors that are easy to obtain. Therefore, we also attempted to determine linear relationships between in vitro $\mathrm{NH}_{3}-\mathrm{N}$ losses and dietary and animal variables. In vitro $\mathrm{NH}_{3}-\mathrm{N}$ losses were not highly correlated to total N intake, DIP-N intake, or DMI, but they were more highly correlated to BW and serum urea-N. However, these higher correlations with BW and serum urea $\mathrm{N}$ are probably related to, and primarily caused by, feeding CP in excess of requirements because excess protein was fed during the third sampling period when animals were at heavier BW and serum urea-N concentrations were highest. Dinn et al. (1996; as cited by Paul et al., 1998) also noted a significant relationship between $\mathrm{NH}_{3}-\mathrm{N}$ emissions from dairy manure and serum urea $\mathrm{N}\left(\mathrm{r}^{2}=0.64\right)$ in dairy cows.

Table 10. Linear relationships $(P<0.001)$ among $7-\mathrm{d}$ ammonia losses and dietary variables or $\mathrm{N}$ excretion ${ }^{\mathrm{a}}$

\begin{tabular}{|c|c|c|c|c|}
\hline Dependent variable & Equation & $\mathrm{R}^{2}$ & Intercept SEM & Slope SEM \\
\hline $\mathrm{NH}_{3}-\mathrm{N}$ loss, mg & $-7.86+(0.0576 \times$ urine $\mathrm{N}, \mathrm{mg})$ & 0.69 & 1.55 & 0.0022 \\
\hline d 30 & $-4.872+(0.043 \times$ urine $\mathrm{N}, \mathrm{mg})$ & 0.80 & 1.05 & 0.0021 \\
\hline d 77 & $-6.054+(0.0508 \times$ urine $\mathrm{N}, \mathrm{mg})$ & 0.74 & 2.21 & 0.003 \\
\hline d 120 & $-6.645+(0.06414 \times$ urine $\mathrm{N}, \mathrm{mg})$ & 0.60 & 4.40 & 0.005 \\
\hline $\mathrm{NH}_{3}-\mathrm{N}$ loss, mg & $-4.206+(0.0654 \times$ urinary urea-N, $\mathrm{mg})$ & 0.58 & 1.76 & 0.003 \\
\hline $\mathrm{d} 30$ & $1.423+(0.0387 \times$ urinary urea-N, $\mathrm{mg})$ & 0.38 & 1.77 & 0.005 \\
\hline d 77 & $-3.21+(0.0587 \times$ urinary urea-N, $\mathrm{mg})$ & 0.60 & 2.34 & 0.004 \\
\hline d 120 & $-6.378+(0.0776 \times$ urinary urea-N, $\mathrm{mg})$ & 0.49 & 5.37 & 0.008 \\
\hline $\mathrm{NH}_{3}-\mathrm{N}$ loss, mg & $-17.89+(0.317 \times \mathrm{N}$ intake, $\mathrm{g})$ & 0.08 & 9.32 & 0.066 \\
\hline $\mathrm{NH}_{3}-\mathrm{N}$ loss, mg & $-11.12+(0.466 \times$ DIP-N intake, $g)$ & 0.08 & 7.27 & 0.088 \\
\hline $\mathrm{NH}_{3}-\mathrm{N}$ loss, mg & $-12.32+(5.76 \times \mathrm{DMI}, \mathrm{kg})$ & 0.04 & 11.72 & 1.73 \\
\hline $\mathrm{NH}_{3}-\mathrm{N}$ loss, mg & $-9.689+(3.84 \times$ SUN $)$ & 0.21 & 4.26 & 0.437 \\
\hline $\mathrm{NH}_{3}-\mathrm{N}$ loss, mg & $-61.44+(0.19973 \times \mathrm{BW}, \mathrm{kg})$ & 0.27 & 8.36 & 0.019 \\
\hline
\end{tabular}

${ }^{a} \mathrm{DIP}-\mathrm{N}$ = dietary ruminally degradable intake $\mathrm{N} ; \mathrm{SUN}=$ serum urea $\mathrm{N}$ concentration $(\mathrm{mg} / 100 \mathrm{~mL})$. 
The in vitro $\mathrm{NH}_{3}-\mathrm{N}$ emissions in this study demonstrate that potential daily $\mathrm{NH}_{3}-\mathrm{N}$ emissions from beef cattle feces and urine can be affected by the $\mathrm{CP}$ and urea concentration of the diet; however, effects on animal performance also must be considered. Based on the results of the complete $\mathrm{N}$ balance trial (Gueye et al., 2003a; McBride et al., 2003) and two performance trials (Gleghorn et al., 2004) using the same diets as used in this trial, the actual CP requirement for optimal performance and maximal $\mathrm{N}$ retention was between 11.5 and $13 \%$ CP. If dietary protein concentrations are decreased to the point that animal performance is adversely affected, then total ammonia emissions could be increased because animals require more days on feed to reach market weight and condition. As animals grow and mature, the $\mathrm{CP}$ required in the diet (as a percentage of DM) decreases. Thus, when the same diet is fed throughout the feeding period, potential ammonia emissions may increase with days on feed. This suggests that the use of phase feeding could potentially decrease ammonia emissions from beef cattle feed yards.

\section{Literature Cited}

Catchpoole, V. R., D. J. Oxenham, and L. A. Harper. 1983. Transformation and recovery of urea applied to a grass pasture in southeastern Queensland. Aust. J. Exp. Agric. Husb. 23:80-86.

Cecava, M. J., and D. L. Hancock. 1994. Effects of anabolic steroids on nitrogen metabolism and growth of steers fed corn silage and corn-based diets supplemented with urea or combination of soybean meal and feather meal. J. Anim. Sci. 72:515-522.

Cole, N. A., L. W. Greene, F. T. McCollum, T. Montgomery, and K. McBride. 2003. Influence of oscillating dietary crude protein concentration on performance, acid-base balance, and nitrogen excretion of steers. J. Anim. Sci. 81:2660-2668.

Dinn, N. E., L. J. Fisher, and J. A. Shelford. 1996. Manipulating ration formulations to reduce nitrogen excretion from lactating cows while maintaining milk production. M.Sc. Thesis. Univ. of British Columbia, Vancouver, Canada.

Erickson, G. E., and T. J. Klopfenstein. 2001a. Managing N inputs and the effect on losses following excretion in open-dirt feedlots in Nebraska. The Sci. World J. 1(S2):830-835.

Erickson, G. E., and T. J. Klopfenstein. 2001b. Nutritional methods to decrease $\mathrm{N}$ losses from open-dirt feedlots in Nebraska. The Sci. World J. 1(S2):836-843.

FASS. 1999. Guide of the Care and Use of Agricultural Animals in Agricultural Research and Teaching. 1st rev. ed. Fed. of Anim. Sci. Soc., Savoy, IL.

Fenn, L. B., and D. E. Kissel. 1976. The influence of cation exchange capacity and depth of incorporation on ammonia volatilization from ammonia compounds applied to calcareous soils. Soil Sci. Soc. Am. J. 40:394-398.

Galyean, M. L., and J. Gleghorn. 2001. Summary of the 2000 Texas Tech University consulting nutritionist survey. Available: http:// www.asft.ttu.edu/burnett_center/progress_reports/bc12.pdf. Accessed June 15, 2002.

Gleghorn, J. F., N. A. Elam, M. L. Galyean, G. C. Duff, N. A. Cole, and J. D. Rivera. 2004. Effects of crude protein concentration and degradability on performance, carcass characteristics, and serum urea nitrogen concentrations in growing and finishing beef steers. J. Anim. Sci. 82:2705-2717.

Gueye, A., C. R. Richardson, J. H. Mikus, G. A. Nunnery, N. A. Cole, and L. W. Greene. 2003a. The effects of dietary crude protein concentration on nitrogen absorption and retention by feedlot steers. J. Anim. Sci. 81(Suppl. 1):209-210. (Abstr.)

Gueye, A., C. R. Richardson, J. H. Mikus, G. A. Nunnery, N. A. Cole, and L. W. Greene. 2003b. Effects of dietary crude protein on serum and urine urea nitrogen in feedlot steers. J. Anim. Sci. 81(Suppl. 1):210. (Abstr.)

Harper, L. A., R. R. Sharpe, and T. B. Parkin. 2000. Gaseous nitrogen emissions from anaerobic swine lagoon: Ammonia, nitrous oxide and dinitrogen gas. J. Environ. Qual. 29:1356-1365.

Hutchinson, G. L., A. R. Mosier, and C. E. Andre. 1982. Ammonia and amine emissions from a large cattle feedlot. J. Environ. Qual. 11:288-293.

Jarvis, S. C., D. J. Hatch, and D. R. Lockyer. 1989. Ammonia fluxes from grazed grasslands: Annual losses from cattle production systems and their relation to nitrogen inputs. J. Agric. Sci. 113:99-108.

Johnson, J. W., and R. L. Preston. 1995. Minimizing nitrogen waste by measuring plasma urea-N levels in steers fed different dietary crude protein levels. Texas Tech Univ. Res. Rep. No. T-5356:62-63.

Kellems, R. O., J. R. Miner, and D. C. Church. 1979. Effect of ration, waste composition, and length of storage on the volatilization of ammonia, hydrogen sulfide and odors from cattle waste. J. Anim. Sci. 48:436-445.

Kissel, D. E., H. L. Brewer, G. F. Arkin. 1977. Design and test of a field sampler for ammonia volatilization. Soil Sci. Soc. Am. J. 41:1133-1138.

Koops, J. G., M. L. van Beusichem, and O. Oenema. 1997. Nitrous oxide production, its source and distribution in urine patches on grassland on peat soil. Plant Soil 191:57-65.

Kumar, P., and R. K. Aggarwal. 1998. Interdependence of ammonia volatilization and nitrification in arid soils. Nutr. Cycl. Agroecosyst. 51:201-207.

Lockyer, D. R., and D. C. Whitehead. 1990. Volatilization of ammonia from cattle urine to grassland. Soil Biol. Biochem. 22:1137-1142.

Luebes, R. E., K. R. Davis, and A. E. Laag. 1974. Diurnal fluctuation and movement of atmospheric ammonia and related gases from dairies. J. Environ. Qual. 3:265-269.

Mason, A. 2004. Nitrogen distribution in pen surface layers of beef cattle feedyards. M.S. Thesis. West Texas A\&M Univ., Canyon.

McBride, K. W., L. W. Greene, N. A. Cole, F. T. McCollum, and M. L. Galyean. 2003. Nitrogen and phosphorus utilization in beef cattle fed three levels of dietary crude protein and three degradable intake protein/undegradable intake protein ratios. J. Anim. Sci. 81(Suppl. 1):73. (Abstr.)

NRC. 2000. Nutrient Requirements of Beef Cattle: Update 2000. 7th ed. Natl. Acad. Press, Washington, DC.

Pandrangi, S., D. B. Parker, L. W. Greene, K. K. Almas, M. B. Rhoades, and N. A. Cole. 2003. Effect of dietary crude protein on ammonia emissions from open-lot beef cattle feedyards. Paper No. 034143 in Proc. 2003 Am. Soc. Agric. Eng. Annu. Int. Mtg., Las Vegas, NV.

Paul, J. W., N. E. Dinn, T. Kannangara, and L. J. Fisher. 1998. Protein content in dairy cattle diets affects ammonia losses and fertilizer nitrogen value. J. Environ. Qual. 27:528-534.

Petersen, S. O., S. G. Sommer, O. Aaes, and K. Soegaard. 1998. Ammonia losses from urine and dung of grazing cattle: Effect of $\mathrm{N}$ intake. Atmos. Environ. 32:295-300.

Ryden, J. C., D. C. Whitehead, D. R. Lockyer, R. B. Thompson, J. H. Skinner, and E. A. Garwood. 1987. Ammonia emission from grassland and livestock production systems in the U.K. Environ. Pollut. 48:173-184.

Shi, Y., D. B. Parker, N. A. Cole, B. W. Auvermann, and J. E. Mehlhorn. 2001. Surface amendments to minimize ammonia emissions from beef cattle feedlots. Trans. Am. Soc. Agric. Eng. 44:677-682.

Smits, M. C. J., H. Valk, A. Elzing, and A. Keen. 1995. Effect of protein nutrition on ammonia emission form a cubical house for dairy cattle. Livest. Prod. Sci. 44:147-156. 
Stewart, B. A. 1970. Volatilization and nitrification of nitrogen from urine under simulated cattle feedlot conditions. Environ. Sci. Tech. 4:579-582.

Tomlinson, A. P., W. J. Powers, H. H. Van Horn, R. A. Nordsedt, and C. J. Wilcox. 1996. Dietary protein effects on nitrogen excretion and manure characteristics of lactating cows. Trans. Am. Soc. Agric. Eng. 39:1441-1448.

Thompson, R. B., and I. R. P. Fillery. 1998. Fate of urea nitrogen in sheep urine applied to soil at different times of the year in the pasture-wheat rotation in south Western Australia. Aust. J. Agric. Res. 49:495-510.
USEPA. 1983. Methods for Chemical Analysis of Waters and Wastes. EPA 600/4-79-020. Revised ed. U.S. Environ. Protect. Agency, Washington, DC.

Whitehead, D. C., D. R. Lockyer, and N. Raistrick. 1989. Volatilization of ammonia from urea applied to soil: Influence of hippuric acid and other constituents of livestock urine. Soil Biol. Biochem. 21:803-808.

Whitehead, D. C., and N. Raistrick. 1991. Effects of some environmental factors on ammonia volatilization from simulated livestock urine applied to soil. Biol. Fertil. Soils 11:279-284. 